\title{
Physical and Chemical Indicators of Surface Waters of the Tatra National Park
}

\author{
Wiktoria Sobczyk ${ }^{1 *}$, Mateusz Wójtowicz'1 , Małgorzata Pawul' \\ 1 AGH University of Science and Technology, Faculty of Mining and Geoengineering, Mickiewicza 30, \\ 30-059 Krakow, Poland \\ * Corresponding author's e-mail: sobczyk@agh.edu.pl
}

\begin{abstract}
The study examines selected physical and chemical indicators of water at four sites in the Tatra National Park and one in Zakopane. The results were compared with the requirements to be met by water intended for human consumption. On the basis of the analyses, the examined samples of water were assessed in terms of their potential use as potable water supplies for the human population. It was found that water collected from selected intake points meets the standards for the tested physical and chemical indicators, which determine the drinkability of water. It was found that the main problem of the Tatra National Park is mass, uncontrolled tourism and tourists who do not comply with the regulations.
\end{abstract}

Keywords: water, national park, pollution, tourism

\section{INTRODUCTION}

A national park is a separated area which protects nature in a comprehensive way. The whole ecosystem is protected: animals, plants, fungi, water, soil, landscape, cultural and historical assets. Educational activities and supporting local traditions and culture are also of great importance. Any work undertaken in the park must not diminish its natural resources. Over 10 million tourists visit 23 Polish national parks. One million people participate in educational events or visit park museums.

Seven Polish national parks with the most valuable natural assets have been included in the World Network of Biosphere Reserves. The Park has enjoyed this status since 1993. The Tatra National Park has $250 \mathrm{~km}$ of hiking trails and the number of visitors oscillates around 3 million a year. The Park area is under strong pressure from mass tourism. There are 8 mountain shelters across the Park. In winter, chairlifts are launched in the Gąsienicowy Basin and the Goryczkowa Valley. A cableway of more than $4 \mathrm{~km}$ in length carries tourists from Kuźnice to Kasprowy
Wierch. Morskie Oko is the most famous Polish mountain lake located in the Rybi Potok Valley. A permanently marked and well-developed network of trails is prepared for tourists. They are classified and color-coded according to different levels of difficulty: from walking paths to alpine trails. The trails also lead to six caves, one of which is illuminated (Mroźna Cave). From 1 May to 30 November, mountain biking is allowed on four marked roads. In addition, horse carriages carry tourists in the Kościeliska, Chochołowska Valleys, on the route to the Morskie Oko, and to the Kalatówki Glade [Sobczyk et al., 2012].

Human activity is the main cause of changes in the physical and chemical properties of water. Water pollution can be caused by industrial and transport accidents and disasters, by discharges of municipal and industrial wastewater which have not been sufficiently treated, by run-off from over-fertilized fields, by leaky septic tanks, unprotected landfills, polluted precipitation, including acid rain. The important physical and chemical parameters of waters include $\mathrm{pH}$, electrolytic conductivity, concentration of nitrate, chloride and sulphate ions and concentration of toxic 
metals, including cadmium. The $\mathrm{pH}$-indicator of water is a scale indicating the acidic or alkaline reaction of the substance. This reaction influences the taste of the water: $\mathrm{pH} 8$ water has an insipid taste, whereas with a higher $\mathrm{pH}$, a soapy aftertaste becomes noticeable. Water has a refreshing taste when its $\mathrm{pH}$ value is below 7.5, when it is cool enough and contains enough carbon dioxide (about $10 \mathrm{mg} / \mathrm{dm}^{3}$ and more). The $\mathrm{pH}$ can be tested using a $\mathrm{pH}$-meter.

Electrolytic conductivity of water is a measure of the ability of a water solution to conduct electricity. This ability depends on the presence of ions, their concentration, mobility, valence and temperature. The solutions of most inorganic compounds are relatively good conductors, while molecules of non-dissociating organic compounds in aqueous solutions do not conduct electricity or conduct it very poorly. Water conductivity measurements, also referred to as conductivity measurements, are mainly used to estimate the total content of dissolved substances [https://analizawody.pl]. Electric conductivity of water is expressed in $\mu \mathrm{S} / \mathrm{cm}$. Its permissible range is $2500 \mu \mathrm{S} / \mathrm{cm}$.

The main causes of nitrate ions entering the waters are the processes of decomposition of organic matter, sewage and runoff from fields treated with nitrogen fertilizers and manure, as well as municipal and industrial sewage. High concentrations of chlorides in water are the result of metabolic changes in living organisms, natural salt leaching, excretion of industrial and municipal wastewater. Exceeded standards pertaining to the permissible concentration of chloride ions in water are characteristic of mine waters. Sulphate ions enter the water along with wastewater from industrial plants, such as coke plants and sulphur mines.

a)

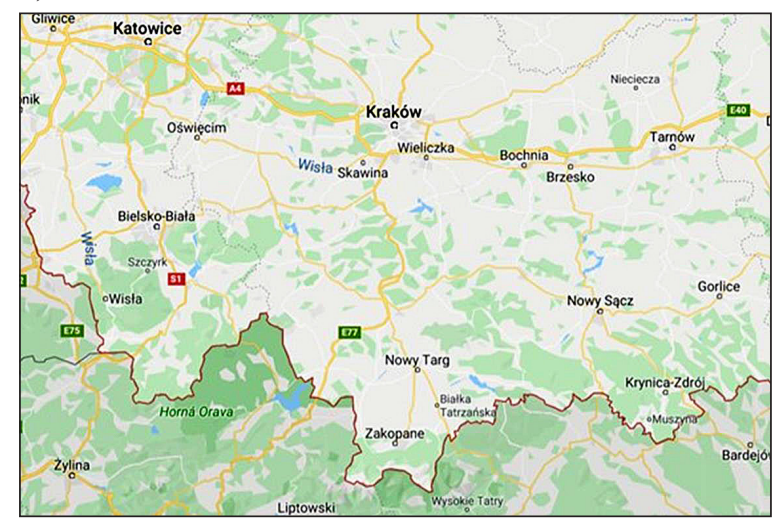

\section{COURSE OF FIELD STUDIES}

The research was conducted in the Tatra National Park and in Zakopane. The sampling points are illustrated in Figures no. 1-3.

The altitude (above sea level) of the sampling points is shown on the hypsometric curve (Figure 4). It was created with reference to the highest point in Poland, which is Rysy (2499 m above sea level).

\section{Description of sampling points}

\section{Sampling point no. 1. The stream flowing into the Czarny Staw Gasienicowy}

- Sampling date: 1 - 6 May 2019

- Sampling altitude: $1660 \mathrm{~m}$ above sea level.

- Sampling locations and sample volumes: blue trail leading from Czarny Staw Gąsienicowy to the Zawrat, 6 water samples collected from the stream: $300 \mathrm{ml}$ each (Figure 5).

- Weather conditions present during sampling: windless, sunny day, air temperature $17^{\circ} \mathrm{C}$.

\section{Sampling point no. 2. The Czarny Staw Gąienicowy}

- Sampling date: 1 - 6 May 2019

- Sampling altitude: $1624 \mathrm{~m}$ above sea level.

- Sampling locations and sample volumes: The Czarny Staw Gąsienicowy, 6 water samples collected from the stream: $300 \mathrm{ml}$ each.

- Weather conditions present during sampling: windless, sunny day, air temperature $17^{\circ} \mathrm{C}$.

\section{Sampling point no. 3. The Foluszowy Potok}

- Sampling date: 1 - 6 May 2019

- Sampling altitude: $880 \mathrm{~m}$ above sea level.

b)

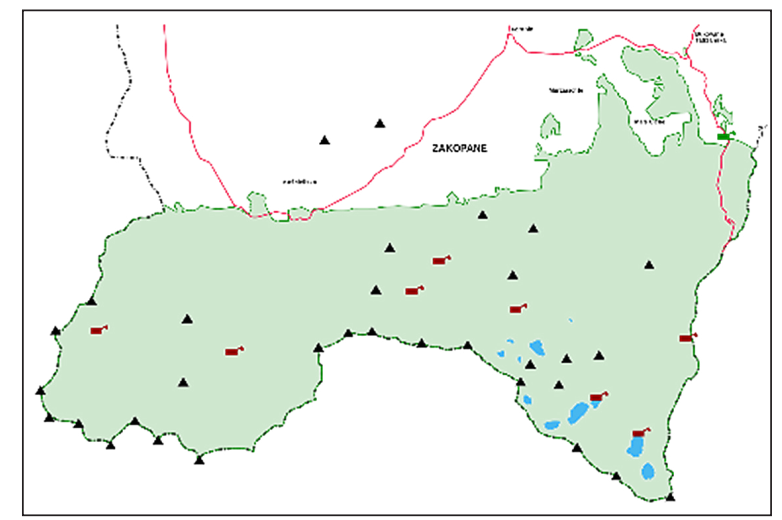

Figure 1. Location of the study site: a - Malopolska region, b - Tatra National Park 


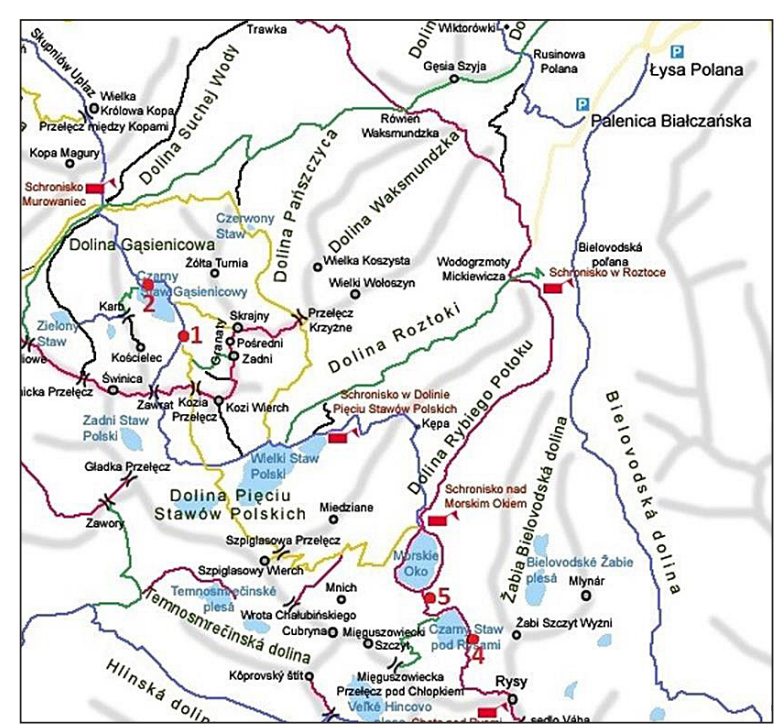

Figure 2. Sampling locations in the Tatra National Park

- Sampling locations and sample volumes: Zakopane, Tytus Chałubiński Street, The Foluszowy Potok, 6 water samples collected from the stream: $300 \mathrm{ml}$ each.

- Weather conditions present during sampling: windless, sunny day, air temperature $20^{\circ} \mathrm{C}$.

\section{Sampling point no. 4. The stream flowing into the Morskie Oko}

- Sampling date: 1 - 6 May 2019

- Sampling altitude: $1420 \mathrm{~m}$ above sea level.

- Sampling locations and sample volumes: red trail leading from Morskie Oko to Czarny Staw under Rysy, 6 water samples collected from the stream: $300 \mathrm{ml}$ each (Figure 6).

- Weather conditions present during sampling: windless, sunny day, air temperature $13^{\circ} \mathrm{C}$.

\section{Sampling point no. 5. The Czarny Staw under Rysy}

- Sampling date: 1 - 6 May 2019

- Sampling altitude: $1583 \mathrm{~m}$ above sea level.

- Sampling locations and sample volumes: The Czarny Staw near Rysy, 6 water samples collected from the stream: $300 \mathrm{ml}$ each (Figure 7).

- Weather conditions present during sampling: windless, sunny day, air temperature $13^{\circ} \mathrm{C}$.

\section{Course of laboratory tests}

The $\mathrm{pH}$, electrolytic conductivity and chloride, sulphate, nitrate and cadmium contents were measured for the water samples. The LF300 photometer was used, which is a universal device designed for water and wastewater analysis. The photometer is equipped with an electronic measuring system controlled by a microprocessor. Executed in the Surface-mount technology (SMD), the instrument guarantees high accuracy, reliability and stability of parameters. Closed measuring tubes with a diameter of $16 \mathrm{~mm}$, made of homogeneous glass, were used as a measuring vessel.

Water samples were poured into beakers, then $\mathrm{pH}$-meter electrodes were immersed in them and measurement results were read from the display. 4 tests were performed for all samples. Each sample underwent the following measurements.

A flat teaspoon of reagent ' 1 ' was added to the $5 \mathrm{ml}$ water sample tube and stirred for 30 seconds. Next, a flat teaspoon of reagent " 2 " was added to the tube and mixed for another 30 seconds. The sample was then left to rest for 5 minutes. After this time, the "nitrate B" indication was set on the photometer, the photometer was zeroed, the tube with the measuring sample was placed in the

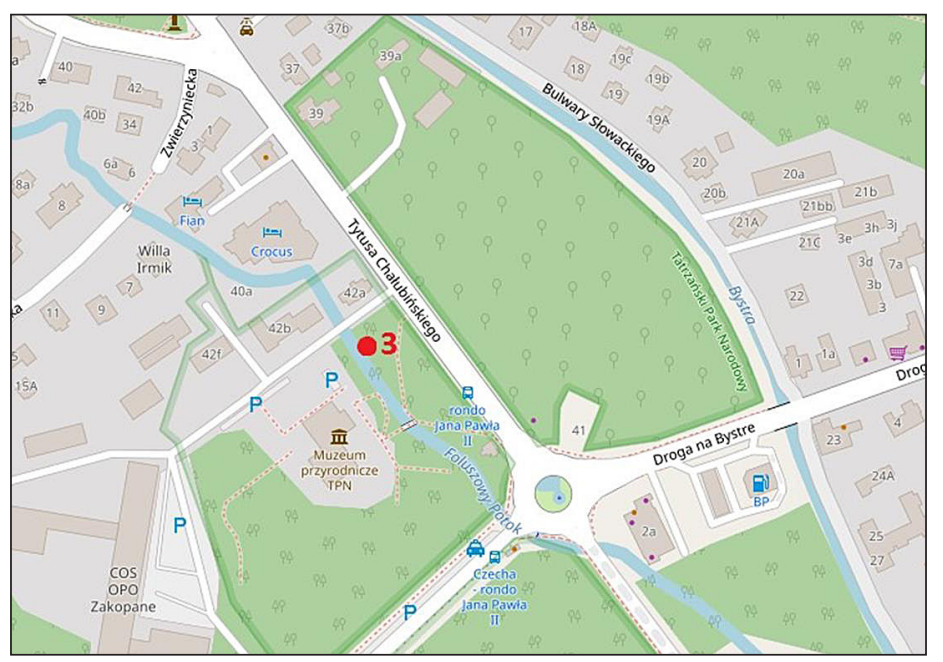

Figure 3. Sampling point in Zakopane (Foluszowy Potok) 


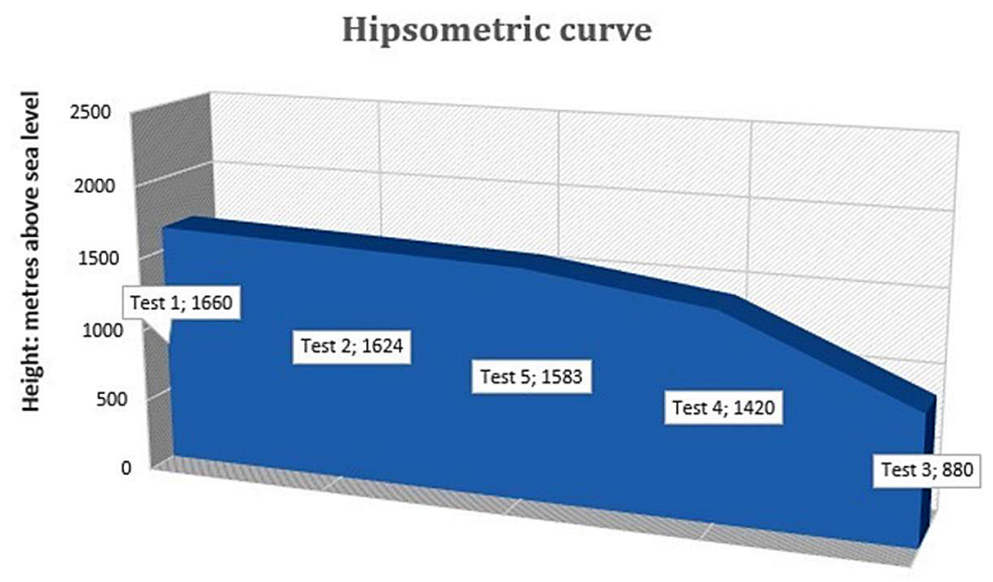

Figure 4. Hypsometric curve illustrating the location of the sampling points relative to sea level [Figure M. Wójtowicz]

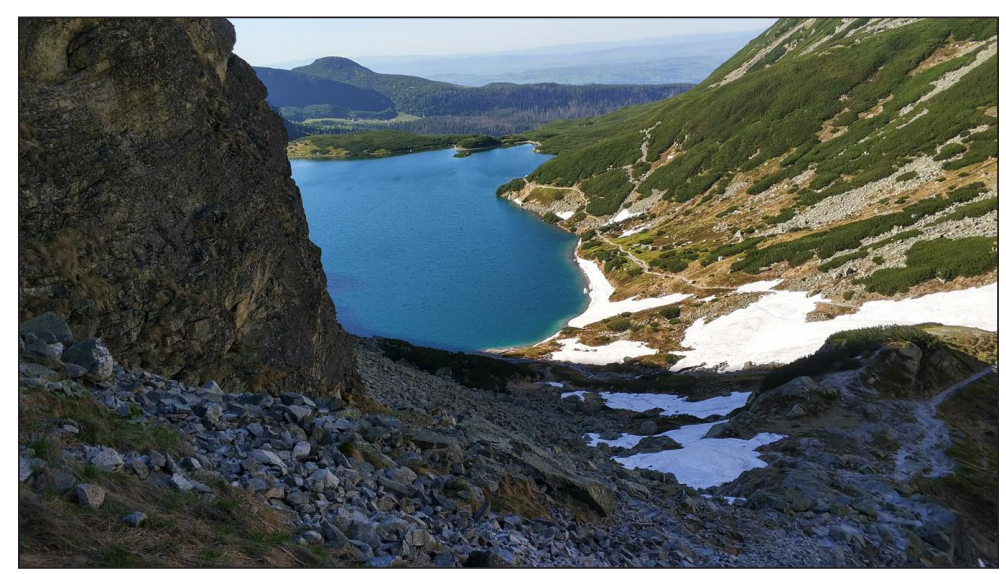

Figure 5. View of Czarny Staw Gąsienicowy. Sampling site [photo M. Wójtowicz]

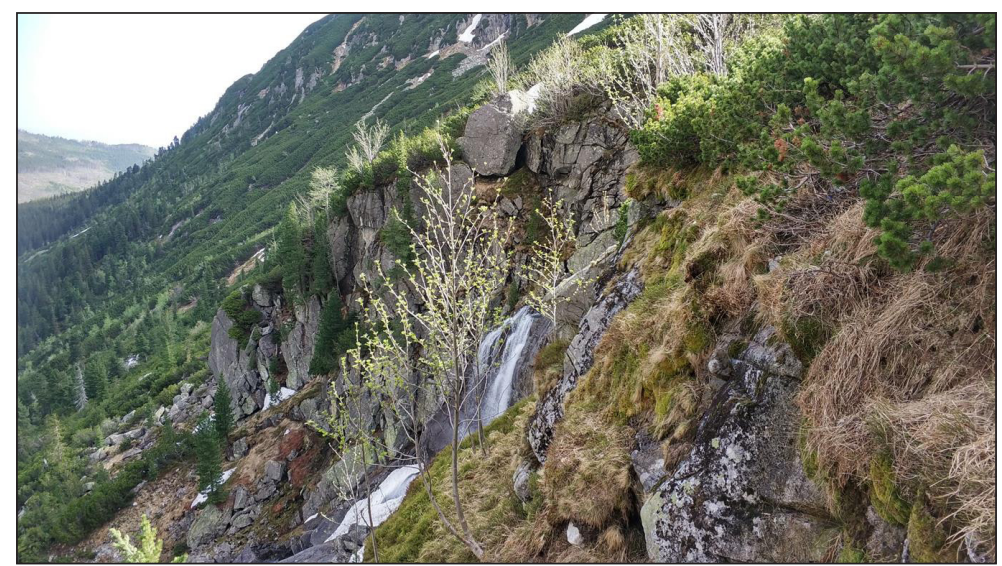

Figure 6. The stream flowing into the Morskie Oko. Sampling site [photo M. Wójtowicz]

measuring socket and the result was read. Then, 6 drops of reagent "1" were added to the next tube ( $5 \mathrm{ml}$ of water), the tube was closed and stirred. After opening the tube, 6 drops of reagent "2" were added, the tube was closed and stirred. The photometer was set to indicate "B chlorides" and, similarly to nitrates, their concentration was measured for water from each sampling point. The results were read from the display. One drop of reagent " 1 " was added to the next tube, the tube was closed and its contents were mixed. After opening the tube, a flat teaspoon of reagent "2" 


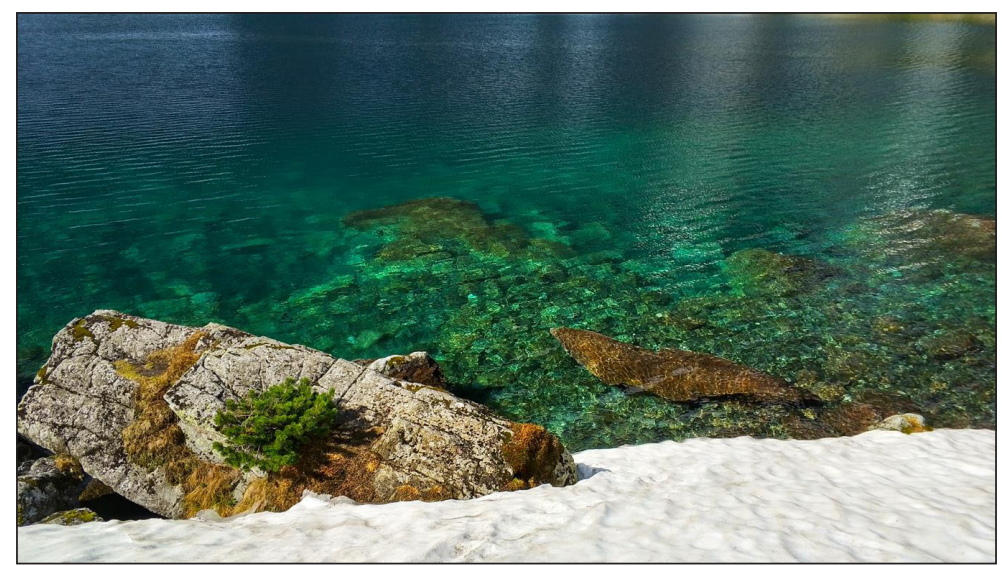

Figure 7. The Czarny Staw near Rysy [photo M. Wójtowicz]

was added, the tube was closed and stirred for 1 minute. After 30 seconds, a similar measurement was made with the photometer, setting the "B sulphate" indication. The measuring tube was filled with $10 \mathrm{ml}$ of sample water to test the cadmium concentration. A flat teaspoon of reagent " 1 " was added to the test tube and the solution was mixed for 30 seconds. Then, 10 drops of reagent " 2 " and 3 drops of reagent " 3 " were added. A measurement was taken after 1 minute. Each measurement was preceded by a photometer reset. The results of laboratory tests (the average from measurements performed for six samples from each point) are shown in Table 1.

On 11 December 2017, a new regulation of the Minister of Health of 7 December 2017 concerning the quality of water intended for consumption entered into force [Rozporządzenie Ministra, 2017]. The regulation imposes new tasks on water supply and sewerage companies, and entities supplied with water from individual intakes. The content of the current Regulation is available on the website of the Legal Acts System.

\section{Analysis of measurement data}

According to the regulation of the Minister of Health, concentrations of hydrogen ions in natural waters should be from 6.5 to 9.5 . $\mathrm{PH}$ values found to be below the required range were recorded at two sites: in Zakopane (6.21) and Czarny Staw pod Rysami (6.26). These values only slightly deviate from the norm, but should be recorded nonetheless. According to the sources [Rozporządzenie Ministra 2017], water has a refreshing taste when its $\mathrm{pH}$ value is below 7.5. At the same time, it is cool and contains enough carbon dioxide (about $10 \mathrm{mg} / \mathrm{dm}^{3}$ ).

Table 1. Average values of selected physical and chemical parameters of water samples

\begin{tabular}{|c|c|c|c|c|c|c|c|}
\hline & Parametr & $\begin{array}{c}\text { Hydrogen ion } \\
\text { concentration } \\
\mathrm{pH} \text { (average } \\
\text { for six } \\
\text { samples) }\end{array}$ & $\begin{array}{c}\text { Conductivity } \\
\text { (at } 25^{\circ} \mathrm{C} \text { ); } \\
\mu \mathrm{S} / \mathrm{cm} \\
\text { (average for } \\
\text { six samples) } \\
\end{array}$ & $\begin{array}{l}\text { Chlorides } \\
\mathrm{mg} / \mathrm{dm}^{3} \\
\text { (average for } \\
\text { six samples) }\end{array}$ & $\begin{array}{l}\text { Sulphureous } \\
\mathrm{mg} / \mathrm{dm}^{3} \\
\text { (average for } \\
\text { six samples) }\end{array}$ & $\begin{array}{c}\text { Nitrates } \\
\mathrm{mg} / \mathrm{dm}^{3} \\
\text { (average for } \\
\text { six samples) }\end{array}$ & $\begin{array}{l}\text { Cadmium } \\
\mu \mathrm{g} / \mathrm{dm}^{3} \\
\text { (average for } \\
\text { six samples) }\end{array}$ \\
\hline 1 & $\begin{array}{l}\text { Permissible ranges / permissible } \\
\text { values }\end{array}$ & $6.5-9.5$ & 2500 & 250 & 250 & 50 & 5 \\
\hline 2 & $\begin{array}{l}\text { The stream flowing into the } \\
\text { Czarny Staw Gąsienicowy (blue } \\
\text { trail leading from Czarny Staw } \\
\text { Gąsienicowy to the Zawrat) }\end{array}$ & 6.69 & 23.1 & 2.06 & $<1$ & $<10$ & 0.054 \\
\hline 3 & The Czarny Staw Gąsienicowy & 6.83 & 23.9 & 7.61 & 1.4 & $<10$ & 0.488 \\
\hline 4 & $\begin{array}{l}\text { The Foluszowy Potok, Tytus } \\
\text { Chałubiński Street, Zakopane }\end{array}$ & 6.21 & 97.5 & 5.77 & 4.8 & $<10$ & 0.105 \\
\hline 5 & $\begin{array}{l}\text { The stream flowing into the } \\
\text { Morskie Oko (red trail leading from } \\
\text { Morskie Oko to Czarny Staw near } \\
\text { Rysy) }\end{array}$ & 6.26 & 37.7 & 4.56 & 2.4 & $<10$ & 0.617 \\
\hline 6 & The Czarny Staw near Rysy & 6.75 & 34.2 & 2.98 & 2.5 & $<10$ & 0.111 \\
\hline
\end{tabular}


Conductivity $(\mu \mathrm{S} / \mathrm{cm})$ at $25^{\circ} \mathrm{C}$ was tested 24 hours after the last sample was taken. It is commonly known to be an indicator of water pollution. The permissible conductivity (at $25^{\circ} \mathrm{C}$ ) for potable water is $2500 \mu \mathrm{S} / \mathrm{cm}$. Most of the water samples taken were characterized by conductivity below $40 \mu \mathrm{S} / \mathrm{cm}$. This phenomenon is characteristic for the peak parts of the Tatra Mountains and results from the fact that they are built of crystalline rocks. Due to the geological structure of the subalpine strata of the Mountains, its waters may exhibit a slightly higher conductivity. The highest conductivity was recorded for the sampling point in Zakopane: $97.5 \mu \mathrm{S} / \mathrm{cm}$. It is less than $4 \%$ of the standard. The conductivity of water samples at the other four sites was between $23.1-37.7 \mu \mathrm{S} / \mathrm{cm}$, i.e. only $1.5 \%$ of the permissible value. The measurement results show a high degree of purity of the water samples.

All of the water samples displayed standard concentrations of chloride ions (standard $250 \mathrm{mg} / \mathrm{dm}^{3}$ ), sulphates (standard $250 \mathrm{mg} / \mathrm{dm}^{3}$ ) and nitrates (standard $50 \mathrm{mg} / \mathrm{dm}^{3}$ ). The highest value of chloride ions was recorded at Czarny Staw Gąsienicowy $\left(7.61 \mathrm{mg} / \mathrm{dm}^{3}\right)$, which was 3\% of the standard. The highest content of sulphates $\left(4.8 \mathrm{mg} / \mathrm{dm}^{3}\right)$, i.e. $1.9 \%$ of the standard, was measured in water at the Zakopane site. In each case, the concentration of nitrates was less than $20 \%$ of the standard.

Among toxic metals, cadmium was chosen for analysis due to the simplicity of measurements. As before, the indications of cadmium concentrations were significantly below the limit value. The highest value was recorded at the Strumyk do Morskiego Oko sampling point: $0.11 \mathrm{mg} / \mathrm{dm}^{3}$, which is only $2.2 \%$ of the standard of $5 \mathrm{mg} / \mathrm{dm}^{3}$.

Based on the analysis of data, it was found that water collected from selected intake points meets the standards for the tested physical and chemical indicators, which determine the drinkability of water [http://www.staff.amu.edu.pl/znaczenie]. At this stage of research, it was impossible to measure the remaining physical or chemical parameters, or the bacteriological contamination of water due to the lack of adequate equipment.

\section{CONCLUSIONS}

Mass tourism is a major issue for the Tatra National Park. Tourists tend to break the rules when traveling on the routes. They interfere with the free movement of animals, scare animals and trample vegetation. Destruction of the dwarf pine, tearing of flowers in bloom and picking fruit are common phenomena. Tourists rest by slopes covered with protected plants, trampling them or even picking them for fun. Every day, the staff of the Tatra National Park witness tourists destroying vegetation, breaking branches, damaging tree bark [Wójtowicz, Sobczyk, 2018].

It should be noted that tourists are not allowed to swim, bathe or wash dirty dishes in mountain reservoirs and rivers. It is a source of drinking water for lodges and a place where rare animal species live [https://tpn.pl/nowosci]. The streams, from which water samples were taken, flow directly into large basins. Mountain lodges use this water for drinking purposes. Nevertheless, it happens that tourists (often intoxicated) jump into the water, polluting the water and posing a threat to themselves and others.

Tourism management in national parks must be consistent with the principles of sustainable development and the idea of national heritage protection [Sobczyk et al., 2012]. This is a significant big challenge for the authorities and the law enforcement. The ecological immaturity of the society, littering areas of natural value with both waste and noise, is also a problem. Comprehensive environmental education of tourists may certainly help improve this situation. Hiking and admiring the natural values of the Tatra Mountains, learning about the history and culture of the region should be always conducted at a high level of personal culture and ecological awareness. Environmental education should be regarded as an integral part of the state's environmental policy.

\section{REFERENCES}

1. Wójtowicz M., Sobczyk W. 2018. Tatra National Park - a pearl of Polish nature. Ekonatura, 6, 24-26.

2. http://www.staff.amu.edu.pl/znaczeniepodstawowychparametrowfizykochem.pdf(access: 14.01. 2020).

3. Rozporządzenie Ministra Zdrowia z dnia 7 grudnia 2017 r. w sprawie jakości wody przeznaczonej do spożycia przez ludzi. Dziennik Ustaw z 11 grudnia 2017, poz. 2294, www.isap.sejm.gov.pl (access: 14 . 01.2020).

4. https://analizawody.pl/glowna/19-odczyn-ph.html (access: 14.01.2020).

5. https://tpn.pl/nowosci/przed-sezonem-garscinformacji (access: 4.02.2020).

6. Sobczyk W., Biedrawa-Kozik A., Kowalska A. 2012. Threats to Areas of Natural Interest. Annual Set The Environment Protection, 14, 262-273. 